\title{
Morphological and Cytotoxic Evaluation in Human Hepatoma Cells (HepG2/C3A) Exposed to Magnetic Nanoparticles
}

Karina Midori Endo ${ }^{*}$, Raquel Dosciatti Bini ${ }^{2 *}$, Elisa Parcero Hernandes ${ }^{1}$, Danielle Lazarin-Bidóia ${ }^{3}$, Veronica Elisa Pimenta Vicentini ${ }^{1}$ and Luiz Fernando Cótica ${ }^{2}$

1. Department of Biotechnology, Genetics and Cell Biology/State University of Maringa - UEM, Maringa, Brazil.

2. Department of Physics/State University of Maringa - UEM, Maringa, Brazil.

3. Department of Pharmaceutical Sciences/State University of Maringa - UEM, Maringa, Brazil.

* Corresponding author: karinaendo@gmail.com

Magnetic iron oxide nanoparticles are highlighting as promising candidates in the nanobiotechnology in a range of applications, such as magnetic hyperthermia, controlled release of drugs in the treatment of cancer, contrast in magnetic resonance, among others [1]. Thus, many efforts are made to develop magnetic nanoparticles (MNPs) in biomedical applications and the coating of the MNPs is a strategy to improve the biocompatibility and mitigate the possible adverse effects of these particles [2]. Therefore, it is of great importance the deep knowledge of the toxicity of nanomaterials, which can be determined by MTT assay, and also their morphological effects, by SEM. The objective of this work was to evaluate the cytotoxicity and morphological changes in cells of human hepatoma (HepG2/C3A), exposed to the MNPs $\left(\mathrm{Fe}_{3} \mathrm{O}_{4}\right)$ and MNPs coated with chitosan $\left(\mathrm{CS}-\mathrm{Fe}_{3} \mathrm{O}_{4}\right)$, using the MTT assay and SEM. For the MTT assay, the cells were treated with different concentrations of $\mathrm{Fe}_{3} \mathrm{O}_{4}$ and $\mathrm{CS}-\mathrm{Fe}_{3} \mathrm{O}_{4}$ for $24 \mathrm{~h}$ and $48 \mathrm{~h}$. For SEM, cells treated with $\mathrm{Fe}_{3} \mathrm{O}_{4}$ and $\mathrm{CS}-\mathrm{Fe}_{3} \mathrm{O}_{4}$ were fixed, dehydrated, critical point-dried in $\mathrm{CO}_{2}$, sputter-coated with gold and observed using a FEI Scios. The MTT assay showed that cells treated with $\mathrm{CS}-\mathrm{Fe}_{3} \mathrm{O}_{4}$ presented no cytotoxicity in all concentrations and incubation periods. However, the treatment with $\mathrm{Fe}_{3} \mathrm{O}_{4}$ induced a reduction of cellular viability in $24 \mathrm{~h}$ and $48 \mathrm{~h}$. Morphological changes were not observed in HepG2/C3A, exposed to the NPMs, demonstrating that the analysis of microscopy was of great importance to note that the cell surface structure was not affected by the interaction with both MNPs. In general, the CS- $\mathrm{Fe}_{3} \mathrm{O}_{4}$ showed better biocompatibility with possibility in conjunction of therapeutic agents in biomedical applications. 
References:

[1] S Behrens, Curr Opin Biotechnol 39 (2016), p. 89.

[2] J Chomoucka et al., Pharmacol Res. 62 (2010), p. 144.

[3] This research was supported by CNPq (Brazil).

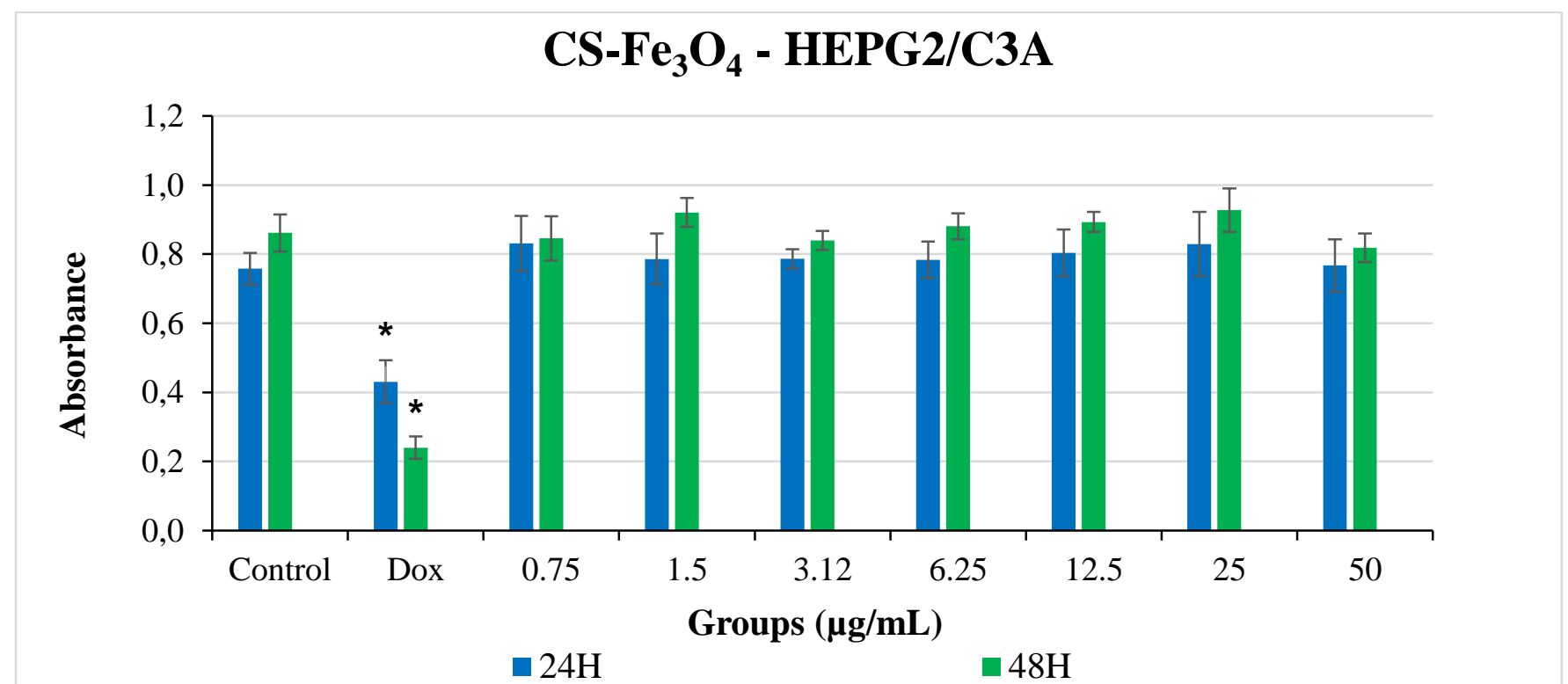

Figure 1. Mean and standard deviation obtained by the MTT test. Groups: Control (DMEM + 10\% FBS), and different concentrations of CS-Fe $\mathrm{O}_{4}(0.75,1.5,3.12,6.25,12.5,25$ and $50 \mu \mathrm{g} / \mathrm{mL})$ were incubated with HepG2/C3A cells for 24 and 48 hours. *Statistically significant difference in relation to control (p $<0.05)$.

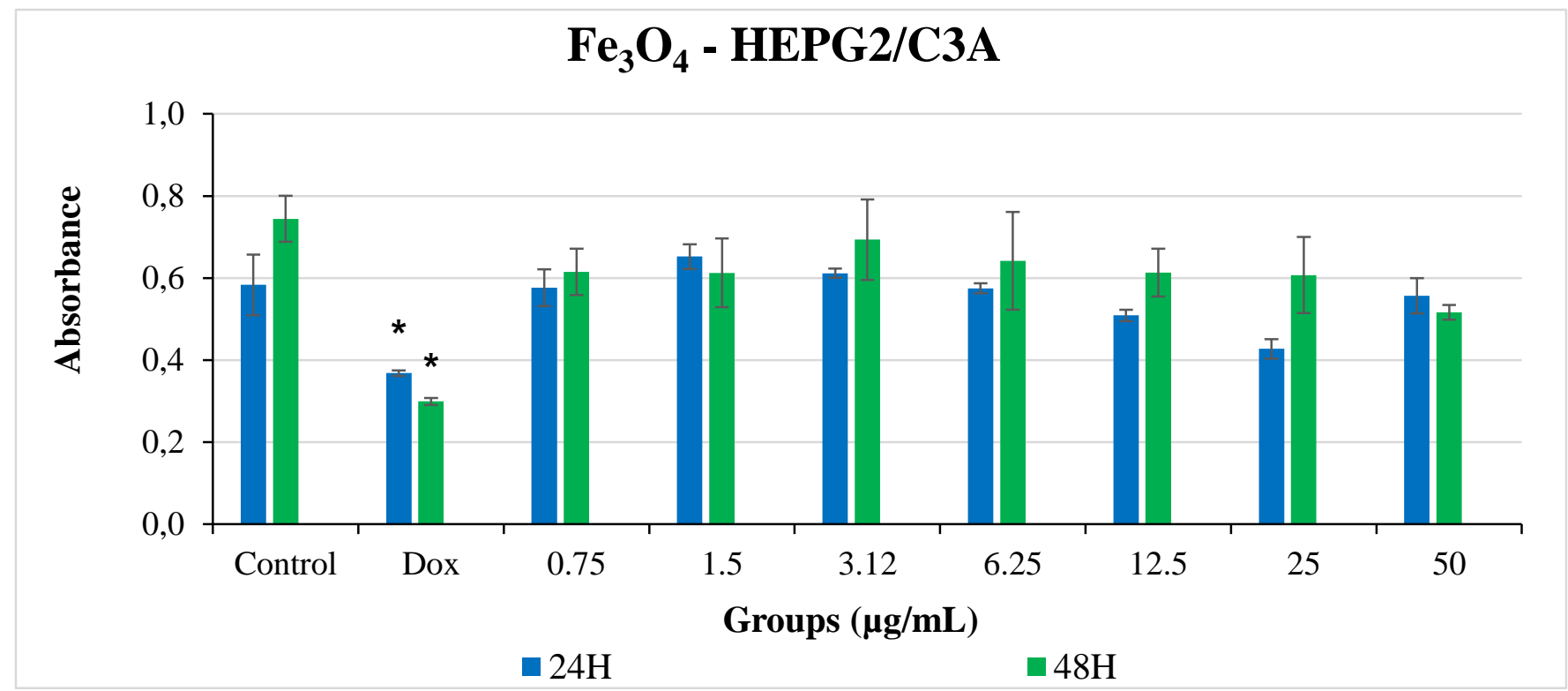

Figure 2. Mean and standard deviation obtained by the MTT test. Groups: Control (DMEM + 10\% FBS), and different concentrations of $\mathrm{Fe}_{3} \mathrm{O}_{4}(0.75,1.5,3.12,6.25,12.5,25$ and $50 \mu \mathrm{g} / \mathrm{mL})$ were incubated with HepG2/C3A cells for 24 and 48 hours. *Statistically significant difference in relation to control ( $\mathrm{p}<0.05)$. 


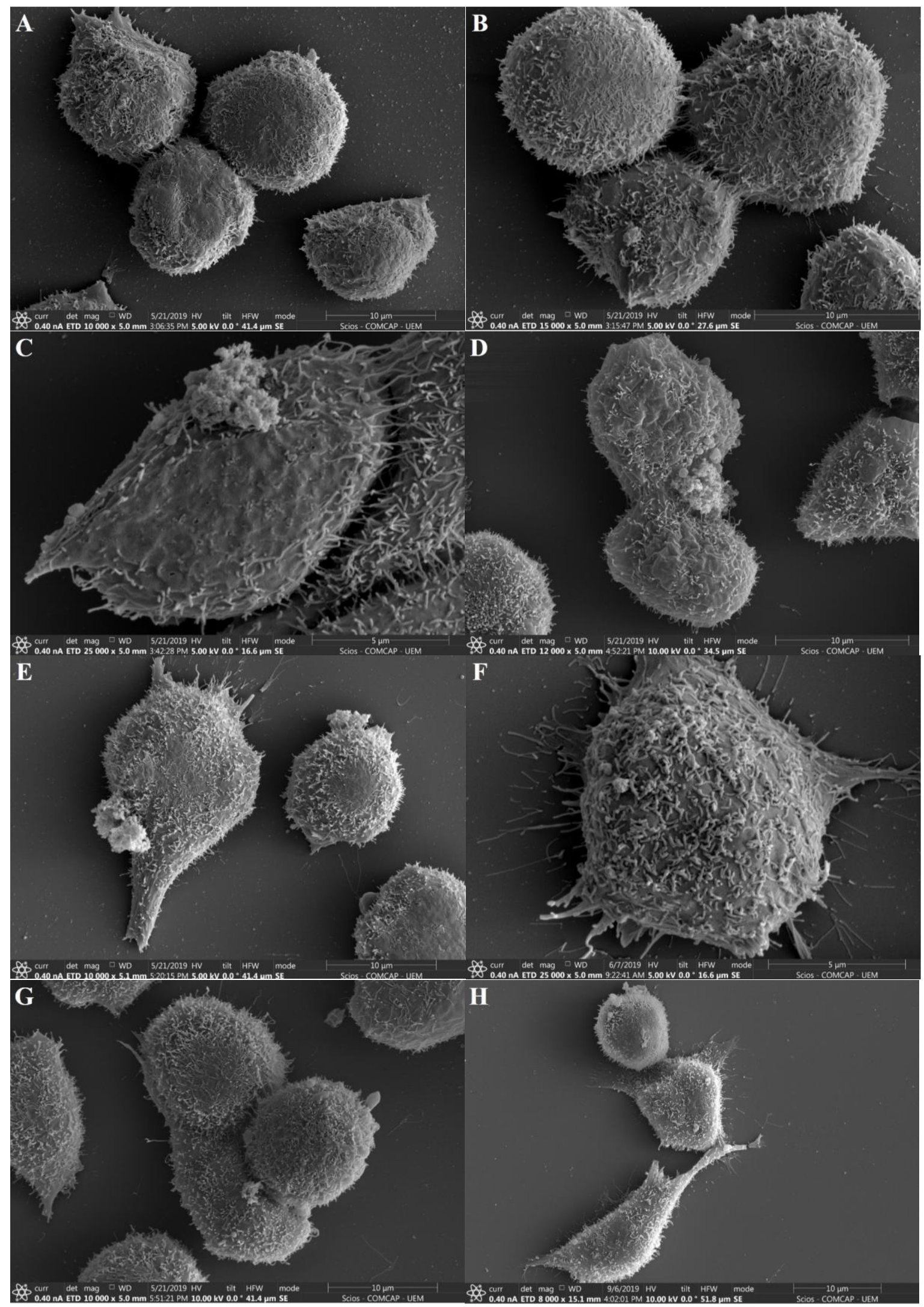

Figure 3. Scanning electron microscopy (SEM) images of HepG2/C3A cells, incubated with different magnetic nanoparticle treatments for 48 hours. (A, B) Control (C) $\mathrm{Fe}_{3} \mathrm{O}_{4} 6.25 \mu \mathrm{g} / \mathrm{mL}$; (D) $\mathrm{Fe}_{3} \mathrm{O}_{4} 25 \mu \mathrm{g} / \mathrm{mL}$; (E) $\mathrm{Fe}_{3} \mathrm{O}_{4} 50 \mu \mathrm{g} / \mathrm{mL}$; (F) CS-Fe $3 \mathrm{O}_{4} 6.25 \mu \mathrm{g} / \mathrm{mL}$; (G) CS-Fe $\mathrm{O}_{4} \mathrm{O}_{4} 25 \mu \mathrm{g} / \mathrm{mL}$; (H) CS-Fe $\mathrm{O}_{4} 50 \mu \mathrm{g} / \mathrm{mL}$. 